\title{
First record of Achatina fulica Bowdich, 1822 (Mollusca, Achatinidae), for the state of Rio Grande do Sul, Brazil
}

\author{
Janine Oliveira Arruda ${ }^{1 *}$ \\ Lúcio dos Santos ${ }^{2}$ \\ 'Museu de Ciências Naturais do Rio Grande do Sul \\ Avenida Dr. Salvador França, 1427, Jardim Botânico, CEP 90.690-000, Porto Alegre - RS, Brasil \\ ${ }^{2}$ Instituto Brasileiro de Meio Ambiente e dos Recursos Naturais Renováveis \\ Rua Miguel Teixeira, 126, Cidade Baixa, CEP 90.050-250, Porto Alegre - RS, Brasil \\ * Autor para correspondência \\ arrudajo@gmail.com
}

Submetido em 30/11/2021

Aceito para publicação em 14/02/2022

\section{Resumo}

Primeiro registro de Achatina fulica Bowdich, 1822 (Mollusca, Achatinidae) para o estado do Rio Grande do Sul, Brasil. Achatina fulica Bowdich, 1822 tem, pela primeira vez para o estado do Rio Grande do Sul, Brasil, sua identificação e presença confirmada por taxonomista. A partir de agora está presente em todos os estados brasileiros. Um espécime jovem foi encontrado no jardim de um condomínio de prédios residenciais no município de Porto Alegre. A hipótese é de que foi acidentalmente introduzido pela empresa de jardinagem. A espécie pode causar prejuízos econômicos e doenças aos seres humanos.

Palavras-chave: Caracol gigante africano; Espécie não-nativa; Lissachatina; Sul do Brasil

\section{Abstract}

Achatina fulica Bowdich, 1822, is here officially recorded for the first time for Rio Grande do Sul State, Brazil. It is now known to occur in every Brazilian state. The species is on the list of the 100 worst invasive species in the world. One young specimen of giant African snail was found in a garden of a residential building in the municipality of Porto Alegre. A hypothesis is that it was accidentally introduced through gardening. It can cause economic losses and diseases in human beings.

Key words: Giant African snail; Lissachatina; Non-native species; South of Brazil

\section{Introduction}

Achatina fulica Bowdich, 1822, popularly known as the giant African snail, is on the list of the 100 worst invasive species in the world (LOWE et al., 2004). It is originally from the African continent, where it occurs from Natal and Mozambique in southern Kenya to Italian Somalia in the north (FISCHER; COLLEY, 2005). Nowadays, this species is widespread on Indian Ocean islands and in Japan, Australia, Southeast Asia and the American continent (ALBUQUERQUE et al., 2008) and is present in 65 countries or territories around the world 
(GISD, 2020). It is one of the most devastating pests in tropical and subtropical regions, causing great damage to farms, commercial plantations and domestic gardens (ALBUQUERQUE et al., 2008).

Achatina fulica is a large land snail. The adults may surpass $12 \mathrm{~cm}$ in length and 5-6 $\mathrm{cm}$ in diameter. The animal has a dark gray tegument and eyes at the top of its tentacles. The shell of the largest specimens can reach $20 \mathrm{~cm}$ long and $8 \mathrm{~cm}$ wide. It can have up to eight whorls that grow quickly in size. The body whorl is the largest and has a wide opening (TELES; FONTES, 2002). The peristome is sharp.

This species exhibits a remarkable reproductive capacity (TELES; FONTES, 2002). According to Ngowsiri et al. (1989), its spawn can contain 100 to 200 eggs that are laid over $24 \mathrm{~h}$. Fischer and Colley (2005) observed oviposits throughout all seasons that contained 10 to 130 eggs and were either spread over the substrate or buried up to $10 \mathrm{~cm}$ deep. The eggs are oval, pale yellow and 0.3 to $0.5 \mathrm{~cm}$ in diameter (UPATHAM et al., 1988). The giant African snail exhibits nocturnal habits and greater activity on rainy days (TELES; FONTES, 2002).

Achatina fulica was found in 25 Brazilian states, except Rio Grande do Sul (THIENGO et al., 2007). Throughout the country it has been recorded in rural, urban areas - e.g., gardens, inside and outside residences, backyards, garbage cans, vacant lots, streets, stables, buildings, etc. - as well as in natural preserved areas (TELES; FONTES, 2002; FISCHER; COLLEY, 2004; 2005; ESTON et al., 2006; THIENGO et al., 2007; ZANOL et al., 2010).

Rio Grande do Sul State is the southernmost state in Brazil, with an area of $281,707 \mathrm{~km}^{2}$ (IBGE, 2021). Its latitude ranges from $27^{\circ} 05^{\prime}$ to $33^{\circ} 45^{\prime} \mathrm{S}$ while the longitude from $49^{\circ} 40^{\prime}$ to $57^{\circ} 38^{\prime} \mathrm{W}$ (approximately). It borders with Santa Catarina state on the north, the Atlantic Ocean on the east, Uruguay on the south and Argentina on the west (RAMBO, 2005). It is the only Brazilian state that holds the Pampa biome, corresponding to approximately $2 / 3$ of the state's area; the other third part is covered by the Atlantic Forest biome (IBGE, 2019). The Pampa biome presents subtropical and temperate climates and grasslands - with sparse shrub and tree formations - as dominant vegetation. Because of its natural grasslands, livestock production is one of the main economic activities (ROESCH et al., 2009).

Rio Grande do Sul is the fourth economy in Brazil considering its Gross Domestic Product. Traditionally it stands out for its agricultural and livestock production. According to data relative to 2015 the agricultural sector had a participation of $12 \%$ in the Gross Value Added of the State. For the same year the composition of the Gross Value of Agricultural Production of Rio Grande do Sul was $68 \%$ for agriculture and $32 \%$ for livestock (ATLAS SOCIOECONÔMICO DO RIO GRANDE DO SUL, 2019).

The presence of this species in Brazil is of great concern, since it is an important agricultural pest in countries of the world where it was introduced (TELES; FONTES, 2002; COLLEY; FISCHER, 2009). In addition, from a sanitary and epidemiological perspective, it is the vector of two known human diseases, namely eosinophilic meningoencephalitis, caused by nematode Angiostrongylus cantonensis (Chen, 1935), and abdominal angiostrongyliasis, caused by Angiostrongylus costaricensis (Morera \& Céspedes, 1971) (TELES; FONTES, 2002; THIENGO et al., 2007; COLLEY; FISCHER, 2009). Both diseases have been recorded for human beings in Brazil (SILVA et al., 2003; LIMA et al., 2009; THIENGO et al., 2010; ESPÍRITOSANTO et al., 2013; BARBOSA et al., 2020).

We present the first official record of A. fulica for Rio Grande do Sul state, the only Brazilian state lacking the presence of this non-native invasive species. This is an important record since the species is an agriculture plague and a vector of angiostrongyliasis.

\section{Material and Methods}

The collection was performed manually on December $5^{\text {th }}, 2020$, at Curupaiti Street, no 1.326 , Cristal neighborhood, Porto Alegre, Brazil, on the garden pavement. The permit collection number of the Brazilian Biodiversity Authorization and Information System is 53680-1. One juvenile specimen was collected and fixed 
according to Thomé (1975) and deposited in the mollusc collection of the Museu de Ciências Naturais do Rio Grande do Sul (Porto Alegre, Brazil). It was identified according to Simone (2006).

\section{Results}

\section{Achatina fulica Bowdich, 1822}

New records. Brazil, Rio Grande do Sul state, Porto Alegre, Cristal neighborhood, Curupaiti Street, no 1.326; 305'26.94”'S 51¹4'25.23”W; 5.XII.2020; Lúcio Santos leg.; manual collection method; MCN 41955.

Identification. A juvenile specimen found was identified as $A$. fulica (Figure 1) by its external characteristics. The shell is 62 millimeter in length; elongated and conical, about twice as long as it is wide; present seven whorls that grow in size quickly; the body's whorl is the largest and has a wide opening; the peristome is sharp. The shell color is reddish-brown with yellowish vertical stripes at the body's whorl and pale yellowish vertical ones at the other whorls. The animal tegument is dark gray; it presents two pairs of tentacles; the eyes are on the top of superior one; there is no fringed lip.

The animal was found in one of the gardens of a residential building at Cristal neighborhood, in Porto Alegre municipality, at twilight, about 7 p.m. All the gardens in there are very well cared for with plants commonly used in gardening (Figure 2).

FIGURE 1: A juvenile specimen of Achatina fulica juvenile found in Porto Alegre municipality, Rio Grande do Sul state, Brazil. Photo by Lúcio Santos.

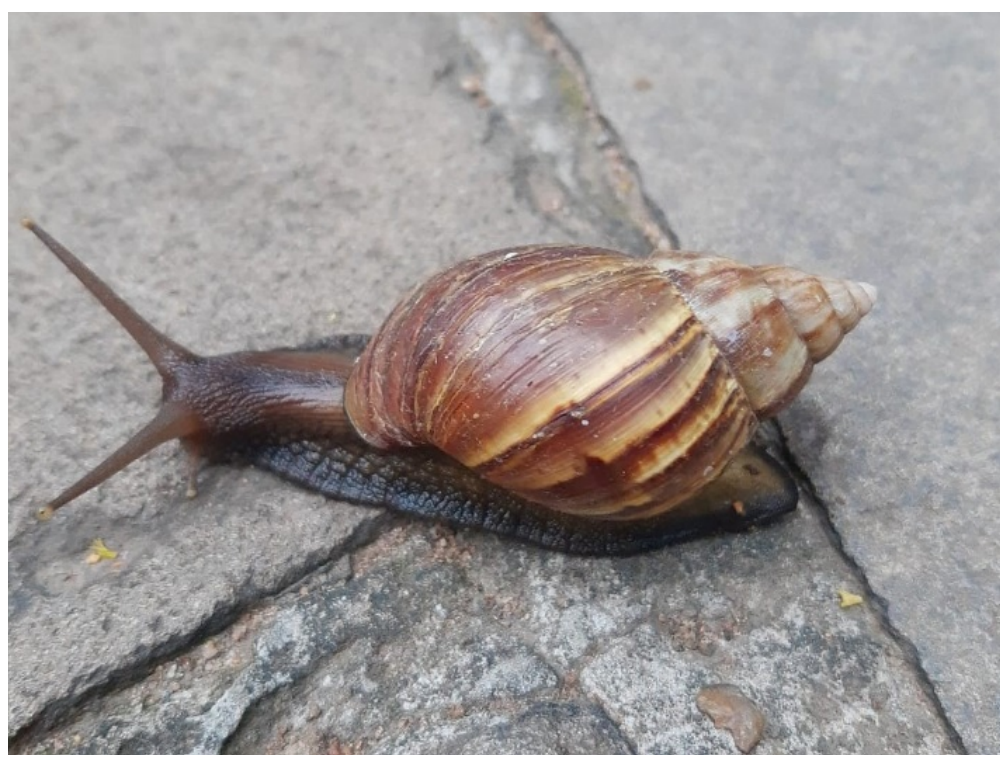

FIGURE 2: Gardens in the building where Achatina fulica was found in Rio Grande do Sul state, Brazil. Photos by Lúcio Santos.
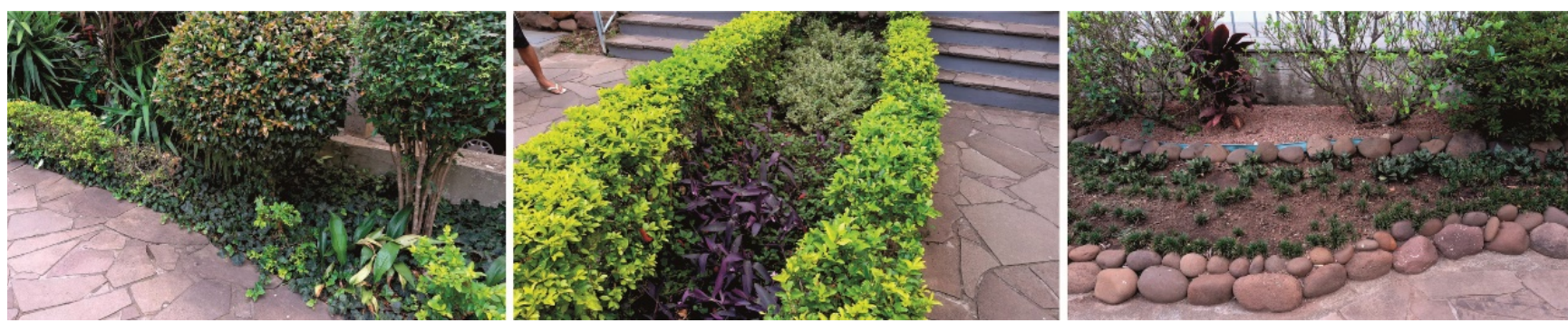


\section{Discussion}

There are countless reasons for the widespread introduction of A. fulica, such as intentionally caused by humans, caused by other animals, as a food source, as a pet, for ornamental and medicinal reasons, accidentally transported with products from agriculture, horticulture and other products commercial vehicles, in addition to transportation along with military equipment (THIENGO et al., 2007). The human being is an important factor for establishment and dispersion of this species, which is more abundant in areas with high human density (ALBUQUERQUE et al., 2008).

The arrival of $A$. fulica in Rio Grande do Sul State (RS) was predictable, since it is present in the Brazilian neighboring state of Santa Catarina (THIENGO et al., 2007) and the neighboring country of Argentina (GREGORIC et al., 2013). Despite its presence for years in the territories north and west of RS, there is no explanation for why this aggressive invasive species was only detected recently in the state and far away from an RS border. Large bodies of water cross both aforementioned borders; however, this species has been recorded on floating mats of vegetation and can survive in water long enough to reach areas downstream (THIENGO et al., 2007). Any of these scenarios could have brought the giant African snail into RS. It is important to point out that many vehicles on roads also carry products between RS and Santa Catarina and Argentina. These activities could also have accidentally dispersed A. fulica many years ago, but this apparently did not happen.

The presence of this species in the RS is of great concern since the state presents vast agriculture and livestock activities in Brazilian economy. In 2013 those activities in the RS were responsible for $12 \%$ of Brazilian Gross Value Added (GVA) and 10.1\% of RS GVA. The RS economy in depends on these sectors more compared to the rest of the country (FEIX et al., 2016). Achatina fulica is considered an important agriculture plague (HODASHI, 1979; EGONMAWAN, 1992; GOLDYN et al., 2016) and its presence in RS lights a warning signal in relation to the possible economic impacts if an effective control is not quickly implemented.
Achatina fulica is known as a vector of Angiostrongylus cantonensis and A. costaricensis that cause zoonotic diseases. Both nematodes are already present in RS (GRAEFF-TEIXEIRA et al., 1990; COGNATO et al., 2013). The giant African snail has a crucial role in the global dispersion of $A$. cantonensis (COGNATO et al., 2013). This new record for RS hereby documented raises concern about the population health and epidemiological impacts.

According to Goldyn et al. (2016) the urban and rural sites are among the most important habitats of A. fulica. The authors considered urban localities as potential important dispersal hotspots, which can threat adjacent agricultural areas. Our hypothesis about how A. fulica arrived in RS, specifically in Porto Alegre, is through gardening. The building where the specimen was found has numerous garden areas that were created and planted by professionals. It is likely that the giant African snail came as eggs or specimens recently hatched in the soil or plants placed there. Similar hypothesis was considered by Gregoric et al. (2013) for the new occurrence of $A$. fulica in Corrientes (Argentina).

Manual control is considered the best form of control (SIMIÃO; FISCHER, 2004) and it has been adopted in Brazilian areas where the species already occurred. The same should be adopted as soon as possible by the health, environmental and agriculture secretaries of the RS in order to control this non-native species.

One of the doormen that works in the building where A. fulica was found mentioned to have seen other specimens of $A$. fulica, bigger than the one here registered. In an inspection of the gardens carried out on January 2, 2021, we found shells of Megalobulimus sp. but no other shell or alive specimen of giant African snail. We infer that the entry of giant African snail in $\mathrm{RS}$ is recent and, as it is unknown to the population, could be confused with a native species with similar shell size and spire.

For an effective control of the A. fulica it is necessary an environmental and health education campaigns that teaches both to differentiate the native species from the non-native one, as well as the correct 
way to proceed with manual collection. This is important since the contamination pathway with Angiostrongylus sp. larvae is through snail mucus.

\section{Acknowledgements}

To Thiago Nunes Antoniazzi for reviewing the English and the anonymous reviews who contributed to improve this work.

\section{References}

ALBUQUERQUE, F. S.; PESO-AGUIAR, M. C.; ASSUNÇÃOALBUQUERQUE, M. J. T. Distribution, feeding behavior and control strategies of the exotic land snail Achatina fulica (Gastropoda: Pulmonata) in the northeast of Brazil. Brazilian Journal of Biology, São Carlos, v. 68, n. 4, p. 837-842, 2008.

ATLAS SOCIECONÔMICO DO RIO GRANDE DO SUL. Economia. 2019. Disponível em: <https://atlassocioeconomico. rs.gov.br/economia>.

BARBOSA, T. A.; THIENGO, S. C.; FERNANDEZ, M. A.; GRAEFF-TEIXEIRA, C.; MORASSUTTI, A. L.; MOURÃO, F. R. P.; MIRANDA, C. O. S.; JORGE, M. M.; GOMES, S. R. Infection by Angiostrongylus cantonensis in both humans and the snail Achatina (Lissachatina) fulica in the city of Macapá, in the Amazon Region of Brazil. Memórias do Instituto Oswaldo Cruz, Rio de Janeiro, v. 115, p. 1-4, 2020.

COGNATO, B. B.; MORASSUTTI, A. L.; SilvA, A. C. A.; GRAEFF-TEIXEIRA, C. First report of Angiostrongylus cantonensis in Porto Alegre, State of Rio Grande do Sul, Southern Brazil. Revista da Sociedade Brasileira de Medicina Tropical, Uberaba, v. 46, n. 5, p. 664-665, 2013.

COLLEY, E.; FISCHER, M. L. Avaliação dos problemas enfrentados no manejo do caramujo gigante africano Achatina fulica (Gastropoda: Pulmonata) no Brasil. Zoologia, Curitiba, v. 26, n. 4, p. 674-683, 2009.

EGONMAWAN, R. I. Food selection in the land Snail Limicolaria flammea Muller (Pulmonata: Achatinidae). Journal of Molluscan Studies, London, v. 58, n. 1, p. 49-55, 1992.

ESPÍRITO-SANTO, M. C. C.; PINTO, P. L. S.; MOTA, D. J. G. D. The first case of Angiostrongylus cantonensis eosinophilic meningitis diagnosed in the city of São Paulo, Brazil. Revista do Instituto de Medicina Tropical de São Paulo, São Paulo, v. 55, n. 2, p. 129-132, 2013.

ESTON, M. R.; MENEZES, G. V.; ANTUNES, A. Z.; SANTOS, A. S. R.; SANTOS, A. M. R. Espécie invasora em Unidade de Conservação: Achatina fulica (Bowdich, 1822) no Parque Estadual Carlos Botelho, Sete Barras, SP, Brasil. Revista do Instituto Florestal, São Paulo, v. 18, p. 173-179, 2006.

FEIX, R. D.; LEUSIN JÚNIOR, S.; AGRANONIK, C. Painel do Agronegócio no Rio Grande do Sul. 2016. Porto Alegre: Fee. Disponível em: <https://www.agricultura.rs.gov.br/upload/ arquivos/201702/10012701-painel-do-agronegocio-do-rio-grandedo-sul-2016.pdf $>$.

FISCHER, M. L.; COLLEY, E. Diagnóstico da ocorrência do caramujo gigante africano Achatina fulica Bowdich, 1822 na APA de Guaraqueçaba, Paraná, Brasil. Revista Estudos de Biologia, Curitiba, v. 26, n. 54, p. 43-50, 2004.

FISCHER, M. L.; COLLEY, E. Espécie invasora em reservas naturais: caracterização da população de Achatina fulica Bowdich, 1822 (Mollusca - Achatinidae) na ilha Rasa, Guaraqueçaba, Paraná, Brasil. Biota Neotropica, Campinas, v. 5, n. 1, p. 127-144, 2005.

GISD - GLOBAL INVASIVE SPECIES DATABASE. Species profile Achatina fulica. 2020. Disponível em: <http://www. iucngisd.org/gisd/species.php?sc=64>.

GOLDYN, B.; GUAYASAMÍN, P. R.; SANCHEZ, K. A. Notes on the distribution and invasion of Achatina fulica Bowdich, 1822 (Gastropoda: Pulmonata: Achatinidae) in Ecuador. Folia Malacologica, Poznań, v. 24, n. 2, p. 85-90, 2016.

GRAEFF-TEIXEIRA, C.; ÁVILA-PIRES, F. D.; MACHADO, R. C. C.; CAMILLO-COURA, L.; LENZI, H. L. Identificação de roedores silvestres como hospedeiros do Angiostrongylus costaricensis no sul do Brasil. Revista do Instituto de Medicina Tropical de São Paulo, São Paulo, v. 32, n. 3, p. 147-150, 1990.

GREGORIC, D. E. G.; BELTRAMINO, A. A.; VOGLER, R. E.; RUMI, A. Expansión del rango de distribución de Achatina fulica Bowdich, 1822 (Gastropoda) en la Argentina y su concordancia con modelos predictivos. Amici Molluscarum, Santiago, v. 21, n. 1, p. 17-21, 2013.

HODASI, J. K. M. Life history studies of Achatina (Achatina) achatina (Linné). Journal of Molluscan Studies, London, v. 45, n. 3, p. 328-339, 1979.

IBGE - INSTITUTO BRASILEIRO DE GEOGRAFIA E ESTATÍSTICA. Biomas e sistema costeiro-marinho do Brasil: compatível com a escala 1:250 000. Rio de Janeiro: IBGE, 2019. $168 \mathrm{p}$.

IBGE - INSTITUTO BRASILEIRO DE GEOGRAFIA E ESTATÍSTICA. Cidades e Estados. 2021. Disponível em: $<$ https:// www.ibge.gov.br/cidades-e-estados/rs/>.

LIMA, A. R. M. C.; MESQUITA, S. G.; SANTOS, S. S.; AQUINO, E. R. P.; ROSA, L. R. S.; DUARTE, F. S.; TEIXEIRA, A. O.; COSTA, Z. R. S.; FERREIRA, M. L. B. Neuroinfestation by Angiostrongylus cantonensis in Recife, Pernambuco, Brazil. Arquivos de Neuro-Psiquiatria, São Paulo, v. 67, n. 4, p.10931096, 2009.

LOWE, S.; BROWNE, M.; BOUDJELAS, S.; DE POORTER, M. 100 of the world's worst invasive alien species a selection from the global invasive species database. Genéve: ISSG/SSC/IUCN, 2004. 12 p.

NGOWSIRI, U.; SERTARUGSA, P.; SOBHON, P.; KRUATRACHUE, M.; CHAVADEJ, J.; UPATHAM, E. S. Development of, and seasonal changes in the reproductive system of Achatina fulica. Journal of the Science Society of Thailand, Bangkok, v. 15, p. 237-249, 1989.

RAMBO, B. A fisionomia do Rio Grande do Sul: ensaio de monografia natural. São Leopoldo Editora: Unisinos, 2005. 473 p. ROESCH, L. F. W.; VIEIRA, F. C. B.; PEREIRA, V. A.; SCHÜNEMANN, A. L.; TEIXEIRA, I. F.; SENNA, A. J. T.; 
STEFENON, V. M. The Brazilian Pampa: a fragile biome. Diversity, Basel, v. 1, n. 2, p. 182-198, 2009.

SILVA, A. C. A.; GRAEFF-TEIXEIRA, C.; ZAHA, A. Diagnosis of abdominal angiostrongyliasis by PCR from sera of patients. Revista do Instituto de Medicina Tropical de São Paulo, São Paulo, v. 45, n. 5, p. 295-297, 2003.

SIMIÃO, M. S.; FISCHER, M. L. Estimativa e inferências do método de controle do molusco exótico Achatina fulica Bowdich, 1822 (Stylommatophora; Achatinidae) em Pontal do Paraná, Litoral do Estado do Paraná. Cadernos de Biodiversidade, Curitiba, v. 4, n. 2, p. 74-83, 2004.

SIMONE, L. R. L. Land and freshwater molluses of Brazil. São Paulo: Fapesp, 2006. 390 p.

TELES, H. M. S.; FONTES, L. R. Implicações da introdução e dispersão de Achatina fulica Bowdich, 1822 no Brasil. Boletim do Instituto Adolfo Lutz, São Paulo, v. 12, n. 1, p. 3-5, 2002.

THIENGO, S. C.; MALDONADO, A.; MOTA, E. M.; TORRES, E. J.; CALDEIRA, R.; CARVALHO, O. S.; OLIVEIRA, A. P. M.; SIMÕES, R. O.; FERNANDEZ, M. A.; LANFREDI, R. M. The giant African snail Achatina fulica as natural intermediate host of Angiostrongylus cantonensis in Pernambuco northeast Brazil. Acta Tropica, Miami, v. 115, p. 194-199, 2010.
THIENGO, S. C.; SAlgADO, N. C.; COWIE, R. W.; FERNANDEZ, M. A. Rapid spread of an invasive snail in South America: the giant African snail, Achatina fulica, in Brazil. Biological Invasions, Dordrecht, v. 9, p. 693-702, 2007.

THOMÉ, J. W. Distensão de moluscos terrestres para fixação, com comentários sobre coleta e transporte. Arquivos do Museu Nacional, Rio de Janeiro, v. 55, p. 153-154, 1975.

UPATHAM, E. S.; KRUATRACHUE, M.; BAIDIKUL, V. Cultivation of the giant African snail, Achatina fulica. Journal of the Science Society of Thailand, Bangkok, v. 14, p. 25-40, 1988.

ZANOL, J.; FERNANDEZ, M. A.; OLIVEIRA, A. P. M.; RUSSO, C. A. M.; THIENGO, S. C. O caramujo exótico invasor Achatina fulica (Stylommatophora, Mollusca) no estado do Rio de Janeiro (Brasil): situação atual. Biota Neotropica, Campinas, v. 10, n. 3, p. $447-451,2010$. 